\title{
The Townes Laser Institute
}

\section{Martin Richardson}

Martin Richardson, "The Townes Laser Institute," Proc. SPIE 9666, 11th Education and Training in Optics and Photonics Conference, $96661 \mathrm{U}$ (5 June 2009); doi: 10.1117/12.2208089

Event: Eleventh International Topical Meeting on Education and Training in Optics and Photonics, 2009, St. Asaph, United Kingdom 


\title{
The Townes Laser Institute
}

\author{
Martin Richardson \\ Townes Laser Institute \\ CREOL The College of Optics \& Photonics \\ University of Central Florida \\ Orlando, Florida, USA
}

\begin{abstract}
The State of Florida has recently established a new center of excellence in advanced core laser technologies, associated with the College of Optics \& Photonics. This center, dedicated in 2007 in tribute to the pioneering work of Charles Townes, whose insight lead to the development of the maser and the laser, will invest in next generation laser technologies for applications to medicine, advanced manufacturing and defense. It joins the cluster of photonics-related centers at UCF, adding a focused national center for the education and training of scientists and engineers in laser technology. This paper describes the mission and objectives of the Townes Institute, the educational and training programs it is creating, its current investments and opportunities, and the future institutional and industrial partnerships and global reach it hopes to create.
\end{abstract}

